\title{
The role of the nurse in caring for the critical patient with sepsis
}

\author{
O papel do enfermeiro perante o paciente crítico com sepse \\ El papel del enfermero ante el paciente crítico con sepsis
}

Maria João Chambel Branco'
ORCID: 0000-0002-1650-0232

Ana Paula Mirco Lucas"

ORCID: 0000-0002-0691-620X

Rita Margarida Dourado Marques"I

ORCID: 0000-0003-2868-7468

Patrícia Pontífice Sousa'

ORCID: 0000-0003-0749-9011

'Universidade Católica Portuguesa. Lisboa, Portugal.

"Centro Hospitalar Lisboa Norte. Lisboa, Portugal.

I'Escola Superior de Saúde de Cruz Vermelha Portuguesa.

Lisboa, Portugal.

How to cite this article:

Branco MJC, Lucas APM, Marques RMD, Sousa PP. The role of the nurse in caring for the critical patient with sepsis.

Rev Bras Enferm. 2020;73(4):e20190031

doi: http://dx.doi.org/10.1590/0034-7167-2019-0031

Corresponding author:

Maria João Chambel Branco

E-mail:mari_branco@hotmail.com

EDITOR IN CHIEF: Antonio José de Almeida Filho ASSOCIATE EDITOR: Italo Rodolfo Silva

Submission: 02-20-2019

Approval: 08-13-2019

\section{ABSTRACT}

Objectives: to know the nursing interventions in the identification, prevention and control of sepsis in critical patients. Methods: integrative review of the literature, with two parallel researches using different MesH terms, using the EBSCO database and Google Scholar. Nine studies were included in the sample. Results: nursing interventions are centered on the creation/implementation of protocols for the early recognition of sepsis, the training of teams to ensure a safe and effective approach and the adoption of measures for infection prevention and control as a way to prevent sepsis. Final Considerations: the evidence shows that nurses are fundamental in the early identification, control and prevention of sepsis, preventing disease progression and contributing to decreased morbidity and mortality. Descriptors: Nurse's Role, Critical Care, Patient, Prevention and Control, Sepsis.

\section{RESUMO}

Objetivos: conhecer as intervenções de enfermagem na identificação, prevenção e controle da sepse no paciente crítico. Métodos: revisão integrativa da literatura, realizadas duas pesquisas paralelas com diferentes descritores $\mathrm{MesH}$, recorrendo à base de dados EBSCO e ao motor de busca Google Acadêmico. Obtiveram-se 9 estudos que integram a amostra. Resultados: as intervenções de enfermagem centram-se na criação/implementação de protocolos que auxiliem o reconhecimento precoce da sepse, na formação das equipes para garantir uma abordagem segura e eficaz e na adoção de medidas que promovam a prevenção e o controle de infeção como forma de prevenir a sepse. Considerações Finais: as evidências demonstraram que o enfermeiro é fundamental na identificação precoce, controle e prevenção da sepse, evitando a progressão da doença e contribuindo para a diminuição da morbilidade e mortalidade.

Descritores: Papel do Enfermeiro; Cuidados Críticos; Paciente; Prevenção \& Controle; Sepse.

\section{RESUMEN}

Objetivos: conocer las intervenciones de enfermería en la identificación, prevención y control de la sepsis en el paciente crítico. Métodos: se trata de una revisión integradora de literatura, llevada a cabo mediante dos investigaciones paralelas con diferentes descriptores $\mathrm{Me} \mathrm{SH}$ recurriendo a la base de datos EBSCO y motor de búsqueda Google Académico. Se obtuvieron 9 estudios que forman parte de la muestra. Resultados: las intervenciones de enfermería están enfocadas en la creación/implantación de protocolos para el reconocimiento precoz de la sepsis, para la formación de equipos que garanticen un abordaje seguro y eficiente y para la adopción de medidas preventivas y de control de la infección para impedir la sepsis. Consideraciones Finales: las evidencias demostraron que el enfermero es fundamental en la identificación temprana, en el control y prevención de la sepsis, para evitar la progresión de la enfermedad y contribuir en la disminución de la morbilidad y de la mortalidad. Descriptores: Papel del Enfermero; Cuidados Críticos; Paciente; Prevención y Control; Sepsis. 


\section{INTRODUCTION}

Critical patients have their life endangered by the failure of one or more vital functions and their survival depends on advanced surveillance, monitoring and treatment. Nursing care is of excellent quality and must be continuous in order to support vital functions, reduce complications and prevent disabilities, aiming at full recovery. These care practices require attentive observation, continuous and systematic monitoring, with the objective of understanding the situation of the patient, predicting and early detecting complications, providing precise, concrete, effective and timely interventions ${ }^{(1)}$.

Sepsis is a systemic inflammatory response to the presence of inflammatory mediators, which are produced by the host in response to microbial agents or toxins. It is considered an acute condition that can rapidly progress to septic shock and multiple organ dysfunction $^{(2)}$. It is a serious public health problem with high mortality rates and significant treatment costs. Compared to stroke and acute myocardial infarction, which have decreased, the incidence of sepsis increases by at least $1.5 \%$ per year. This increase is related to the aging of the population, greater longevity of people with chronic diseases, growing number of immunocompromised patients and increased use of invasive techniques ${ }^{(3)}$. The clinical manifestations of sepsis are varied and depend on several factors, such as the etiology of the infection, the comorbidities and personal characteristics of the patient and the duration of evolution ${ }^{(4)}$.

The implementation of a sepsis therapeutic protocol not only reduces mortality rates, but also considerably reduces healthcare $\operatorname{costs}^{(3)}$. Recent evidence has demonstrated the efficacy of early warning systems to identify patients at risk or whose condition is deteriorating ${ }^{(5)}$. Considering that sepsis is a critical disease and that delayed diagnosis and therapy is associated with increased morbidity and mortality, the role of nurses in the early recognition of changes is extremely important. Early recognition of sepsis, prompt and proper intervention in the early hours may prevent the condition from progressing ${ }^{(6)}$. Therefore, nurses must develop specialized skills, responding to the needs of patients with sepsis, which will lead to improved health outcomes and costs.

\section{OBJECTIVES}

To know the nursing interventions in the identification, prevention and control of sepsis in critical patients.

\section{METHODS}

\section{Ethical aspects}

This research did not involve human beings; therefore, it did not require approval from a research ethics committee.

However, it followed the rules of good scientific conduct, based on rigorous referencing and respect for the authors' perspectives.

\section{Type of study}

This study is an integrative review. This type of review provides a systematic and broad analysis of scientific research, enabling the characterization and dissemination of the knowledge produced.
Its purpose is to gather and synthesize results of studies on a particular theme or issue, in a systematic and orderly manner ${ }^{(7)}$.

Its elaboration is based on six steps: identification of the theme and selection of the research question, establishment of inclusion and exclusion criteria, categorization of studies, quality assessment of studies included in the review, interpretation of results and presentation of the review/synthesis of knowledge $\mathrm{e}^{(8-9)}$.

Research is important for establishing a scientific basis that can guide the practice of care $^{(7)}$. Evidence-based practice the conscientious, explicit, and judicious use of current best evidence in making decisions about the care of individual patients. Its use has increased the need to develop all types of literature reviews, including integrative reviews ${ }^{(10-11)}$.

\section{Methodological procedures}

The first step consisted of the formulation of a research question using the PI[C]OD method: participants, intervention, (comparison), outcomes and design ${ }^{(11)}$. Based on this method, the following research question was formulated: "What are the nursing interventions in the identification, prevention and control of sepsis in critical patients?"

The sampling process was elaborated in step 2, which established the inclusion and exclusion criteria for this review, presented in Chart 1.

The initial identification and selection of studies was carried out using the keywords validated as MeSH terms: sepsis, prevention and control, nursing, diagnosis. Subsequently, inclusion and exclusion criteria were defined according to the research question (Chart 1). Two parallel researches were conducted in order to obtain a sufficient number of articles relevant for the study.

In the first research, the following research strategy was used: sepsis AND prevention and control AND nursing. In the second, the strategy used was: sepsis AND diagnosis AND nursing. Given the nature of the integrative review and with the objective of gathering a larger number of articles, the Google Scholar was also used.

Chart 1 - Inclusion and exclusion criteria

\begin{tabular}{|c|c|c|}
\hline Selection criteria & Inclusion criteria & Exclusion criteria \\
\hline $\begin{array}{l}1^{\text {st }} \text { research step } \\
\text { (application of } \\
\text { criteria in the } \\
\text { search engines) }\end{array}$ & $\begin{array}{l}\text { - Full articles available } \\
\text { online; } \\
\text { - Articles in English } \\
\text { and Portuguese. }\end{array}$ & $\begin{array}{l}\text { - Documents prior to } \\
\text { the year } 2013 \text {. }\end{array}$ \\
\hline $\begin{array}{l}2^{\text {nd }} \text { research step } \\
\text { (adequacy of title } \\
\text { and abstract) }\end{array}$ & $\begin{array}{l}\text { - Inclusion of adults/ } \\
\text { older adults in the } \\
\text { study; } \\
\text { - Nursing approach to } \\
\text { the patient with sepsis. }\end{array}$ & $\begin{array}{l}\text { - Documents written } \\
\text { in a language other } \\
\text { than those in the } \\
\text { inclusion criteria; } \\
\text { - Inclusion of patients } \\
\text { under } 18 \text { years of age; } \\
\text { - Operating room } \\
\text { context; } \\
\text { - Duplicated articles. }\end{array}$ \\
\hline $\begin{array}{l}3^{\text {rd }} \text { research step } \\
\text { (full reading) }\end{array}$ & $\begin{array}{l}\text { - Study partially } \\
\text { answers the research } \\
\text { questions. }\end{array}$ & $\begin{array}{l}\text { - Study does not } \\
\text { answer the research } \\
\text { questions. }\end{array}$ \\
\hline
\end{tabular}




\section{Data collection and organization}

Data was collected and organized from September 25 to October 6, 2018 on the following database search engines: EBSCO (CINAHL Complete, MEDLINE Complete, Nursing \& Allied Health Collection: Comprehensive, Database of Abstracts of Reviews of Effects, Cochrane Central Register of Controlled Trials, Cochrane Database of Systematic Reviews, Cochrane Methodology Register, Library, Information Science \& Technology Abstracts, MedicLatina,), Google Scholar and the scientific repository of the Portuguese Catholic University.

The third step was the organization, summarization and categorization of the articles, presented in Chart 2. The level of evidence was classified according to the New Joanna Brigs Institute (JBI) Levels of evidence, which allows a preliminary judgment of the methodological quality and rigor of the evidence ${ }^{(12)}$. In addition to the use of this method and according to recommendations ${ }^{(12-13)}$, careful reading, critical evaluation and clinical reasoning were used.

There were 2 level 2.c studies (Quasiexperimental prospective controlled study) (14-15), 1 level 2.d study (Pre-test - post-test or historic/retrospective control group study) (16), 3 level 4.a studies (Systematic review of descriptive studies) $)^{(17-19)}, 1$ level 4.b study (Cross-sectional study) $^{(20)}, 1$ level 5.a study (Systematic review of expert opinion) ${ }^{(5)}$ and 1 level 5.c study (Single expert opinion)(21).

The JBI instrument "Checklist for Diagnostic Test Accuracy Studies" was used to evaluate the methodological quality ${ }^{(22)}$. Two independent reviewers conducted the critical evaluation, the extraction and synthesis of the data. Full reading and evaluation of the methodological quality of the studies were conducted to ensure critical evaluation during the article selection process. Due to some disagreements between the researchers, the evaluation of a third person was requested. All studies were of high quality, so none were excluded after this evaluation.

\section{Data analysis}

In the fourth step, the studies included were evaluated and interpreted. A critical analysis was conducted, highlighting the main results related to nursing interventions in the identification, prevention and control of sepsis in critical patients, as presented in Chart 3. In the next step, the interpretation/discussion of the results and potential gaps were presented. Finally, the knowledge about nurses' actions in the identification, prevention and control of sepsis was synthesized, highlighting the relevance of this review.

\section{RESULTS}

After applying the inclusion and exclusion criteria, 9 articles were selected for the sample, 6 found in the EBSCO database and 3 in Google Scholar (Figure 1).

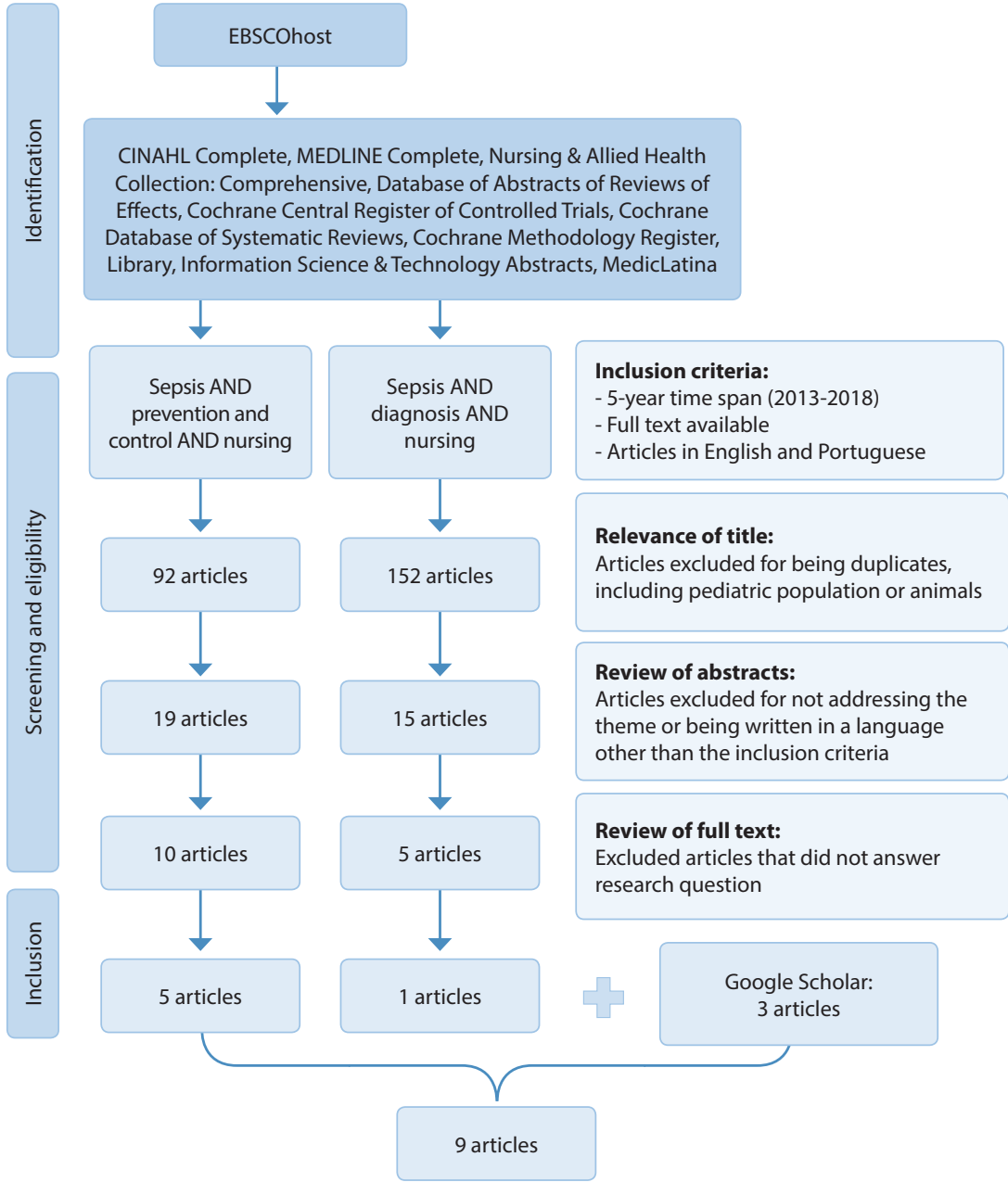

Figure 1 - Flowchart of the research screening process

Chart 2 - Synthesis of the articles included in the integrative review

\begin{tabular}{|l|c|l|l|c|}
\hline \multicolumn{1}{|c|}{ Title } & $\begin{array}{c}\text { Year/ } \\
\text { Country }\end{array}$ & \multicolumn{1}{|c|}{ Design/sample } & $\begin{array}{c}\text { Level of } \\
\text { evidence } \\
\text { (JBI) (12) }\end{array}$ \\
\hline $\begin{array}{l}\text { Knowledge of the professional } \\
\text { nurse about sepsis } \\
\text { (Article 1) }\end{array}$ & $\begin{array}{l}2013, \\
\text { Brazil }\end{array}$ & $\begin{array}{l}\text { Descriptive, cross-sectional, quantitative } \\
\text { and qualitative study. } \\
\mathrm{n}=9 \text { nurses }\end{array}$ & $\begin{array}{l}\text { Identify the knowledge of nurses from } \\
\text { an intensive care unit about sepsis. }\end{array}$ & $4 . \mathrm{b}$ \\
\hline
\end{tabular}


Chart 2 (concluded)

\begin{tabular}{|c|c|c|c|c|}
\hline Title & $\begin{array}{l}\text { Year/ } \\
\text { Country }\end{array}$ & Design/sample & Interventions & $\begin{array}{l}\text { Level of } \\
\text { evidence } \\
(\mathrm{JBI})^{(12)}\end{array}$ \\
\hline $\begin{array}{l}\text { Implications of the New International } \\
\text { Sepsis Guidelines for nursing } \text { care }^{(5)} \\
\text { (Article 2) }\end{array}$ & $\begin{array}{l}2013, \\
\text { United } \\
\text { States }\end{array}$ & Systematic review of expert opinion. & $\begin{array}{l}\text { Present recommendations for the } \\
\text { treatment of adult patients with sepsis. }\end{array}$ & 5.a \\
\hline $\begin{array}{l}\text { Nurses can help improve outcomes } \\
\text { in severe sepsis }{ }^{(21)} \\
\text { (Article 3) }\end{array}$ & $\begin{array}{l}2016 \\
\text { United } \\
\text { States }\end{array}$ & Opinion piece (from an expert). & $\begin{array}{l}\text { Discuss the nurse's role in the early } \\
\text { identification of sepsis, considering } \\
\text { existing guidelines. }\end{array}$ & 5.c \\
\hline $\begin{array}{l}\text { Scripting Nurse Communication to } \\
\text { improve sepsis care }{ }^{(16)} \\
\text { (Article 4) }\end{array}$ & $\begin{array}{l}2016 \\
\text { United } \\
\text { States }\end{array}$ & $\begin{array}{l}\text { Quasi-experimental study (pre-test/post- } \\
\text { test, one group). } \\
n=681 \text { nurses of a Trauma Hospital }\end{array}$ & $\begin{array}{l}\text { Identify the role of nurses in the } \\
\text { development a sepsis treatment } \\
\text { program. }\end{array}$ & 2.d \\
\hline $\begin{array}{l}\text { Early identification of sepsis in } \\
\text { hospital inpatients by ward nurses } \\
\text { increases } 30 \text {-day survival }{ }^{(14)} \\
\text { (Article 5) }\end{array}$ & $\begin{array}{l}2016 \\
\text { Norway }\end{array}$ & $\begin{array}{l}\text { Quasi-experimental prospectively } \\
\text { controlled study. } \\
\text { Pre-intervention group } \\
n=472 \text { patients } \\
\text { Post-intervention group } \\
n=409 \text { patients }\end{array}$ & $\begin{array}{l}\text { Investigate whether implementation } \\
\text { of a clinical tool for triage of systemic } \\
\text { inflammatory response syndrome and } \\
\text { organ failure could improve clinical } \\
\text { observations in an emergency hospital. }\end{array}$ & 2.c \\
\hline $\begin{array}{l}\text { Early Sepsis Identification }{ }^{(15)} \\
\text { (Article 6) }\end{array}$ & $\begin{array}{l}2017 \\
\text { United } \\
\text { States }\end{array}$ & $\begin{array}{l}\text { Quasi-experimental prospectively } \\
\text { controlled study. }\end{array}$ & $\begin{array}{l}\text { Facilitate early recognition of signs and } \\
\text { symptoms of sepsis through utilization } \\
\text { of a screening tool for nurses on } \\
\text { medical and surgical units. }\end{array}$ & 2.c \\
\hline $\begin{array}{l}\text { Performance of emergency nurses } \\
\text { in sepsis control }{ }^{(17)} \\
\text { (Article7) }\end{array}$ & $\begin{array}{l}2018 \\
\text { Brazil }\end{array}$ & $\begin{array}{l}\text { Systematic literature review. } \\
13 \text { articles }\end{array}$ & $\begin{array}{l}\text { Analyze the actions of emergency } \\
\text { nurses in sepsis control. }\end{array}$ & 4.a \\
\hline $\begin{array}{l}\text { Sepsis: importance of early } \\
\text { identification by nursing }{ }^{(18)} \\
\text { (Article } 8 \text { ) }\end{array}$ & $\begin{array}{l}2018 \\
\text { Brazil }\end{array}$ & $\begin{array}{l}\text { Integrative literature review. } \\
11 \text { articles }\end{array}$ & $\begin{array}{l}\text { Demonstrate the importance of nursing } \\
\text { in the diagnosis and treatment of sepsis. }\end{array}$ & 4.a \\
\hline $\begin{array}{l}\text { Nursing care for patients with sepsis } \\
\text { in intensive care units: a literature } \\
\text { review }^{(19)} \\
\text { (Article 9) }\end{array}$ & $\begin{array}{l}2018 \\
\text { Brazil }\end{array}$ & $\begin{array}{l}\text { Integrative literature review. } \\
10 \text { articles }\end{array}$ & $\begin{array}{l}\text { Analyze the care provided to people } \\
\text { with sepsis in an intensive care unit. }\end{array}$ & 4.a \\
\hline
\end{tabular}

Chart 3 - Main results of articles included

\begin{tabular}{|c|c|}
\hline Article & Outcomes \\
\hline Article $1^{(20)}$ & $\begin{array}{l}\text { - All nurses showed an adequate knowledge of the concept of sepsis, however, } 33.3 \% \text { demonstrated lack of scientific knowledge } \\
\text { about signs of infection, systemic inflammatory response syndrome, severe sepsis, septic shock, and forms of treatment; } \\
\text { - Only } 11.1 \% \text { of nurses recognized hypothermia as a sign of sepsis; } \\
\text { - The nurses indicated the need to support continuing education and create/implement sepsis bundles, improving quality of care and } \\
\text { reducing mortality rates. }\end{array}$ \\
\hline Article $2^{(5)}$ & $\begin{array}{l}\text { - The new guidelines indicate that lack of early recognition of sepsis is a major obstacle to initiation of treatment; } \\
\text { - It is important to manage patient/family expectations, establish realistic treatment and promote communication; } \\
\text { - Integration of the new recommendations into nursing practice ensures specialized quality care, preventing advanced stages of sepsis. }\end{array}$ \\
\hline Article $3^{(21)}$ & $\begin{array}{l}\text { - The early identification of sepsis by nurses contributes to better outcomes for the patient; } \\
\text { - Nurses have the important role of coordinating communication between the multidisciplinary team and the patient/family. Lack of } \\
\text { communication can delay diagnosis and treatment; } \\
\text { - Training/education of nurses is essential for the provision of better care; } \\
\text { - Better ratios allow a correct assessment of the person and an early identification of sepsis. }\end{array}$ \\
\hline Article $4^{(16)}$ & $\begin{array}{l}\text { - In the post-test period, nurses rated themselves as significantly more experienced about sepsis than at baseline; } \\
\text { - In the post-test, there was a decrease in the number of patients who did not receive the correct screening }(40.6 \% \text { to } 8.9 \%) ; \\
\text { - Having trained nurses able to implement sepsis protocols based on current evidence results in lower variability in screening and } \\
\text { reduces diagnostic errors. }\end{array}$ \\
\hline Article $5^{(14)}$ & $\begin{array}{l}\text { - During the hospital stay, more patients in the pre-intervention group had deterioration of their general condition compared to the } \\
\text { post-intervention group; } \\
\text { - At } 7 \text { days after analytical confirmation of infection, } 4.6 \% \text { of patients in the pre-intervention group had died compared to } 3.4 \% \text { in the } \\
\text { post-intervention group; } \\
\text { - At } 30 \text { days after analytical confirmation of infection, } 12.5 \% \text { of the patients in the pre-intervention group had died compared to } 7.1 \% \\
\text { in the post-intervention group; } \\
\text { - A more accurate assessment in the post-intervention group reduced the need for advanced treatment, decreasing admissions to } \\
\text { intensive care units. }\end{array}$ \\
\hline
\end{tabular}




\begin{tabular}{|l|l|}
\hline Article & \multicolumn{1}{c|}{ Outcomes } \\
\hline Article $6^{(15)}$ & $\begin{array}{l}\text { - The number of identified sepsis cases increased from 6.7\% to } 84.2 \% \text { in Hospital 1, and from } 22.6 \% \text { to } 45.2 \% \text { in Hospital 2; } \\
\text { - Time of notification decreased by } 42 \text { minutes in Hospital 1, while in Hospital } 2 \text { the mean was } 138 \text { minutes. }\end{array}$ \\
\hline Article $7^{(17)}$ & $\begin{array}{l}\text { - The nurse is an important professional in the control of sepsis, through the implementation of preventive measures and monitoring } \\
\text { of clinical parameters: signs of hypoperfusion, decreased level of consciousness, altered body temperature, decreased urinary output, } \\
\text { blood pressure and oxygen levels; } \\
\text { - The nurse should be aware of the precautions that must be taken when performing invasive procedures in order to prevent the risk } \\
\text { of infection caused by microorganisms in the hospital environment. }\end{array}$ \\
\hline Article $8^{(18)}$ & $\begin{array}{l}\text { - An important factor for determining sepsis: sources of contamination, that is, the conditions of the hospital environment, quality of } \\
\text { materials, asepsis, implementation of standards and routines, and use of personal protective equipment; } \\
\text { - Knowing the characteristics of the disease helps in early diagnosis, providing more accurate and safe interventions that contribute to } \\
\text { the prevention of complications. }\end{array}$ \\
\hline Article $9^{(19)}$ & $\begin{array}{l}\text { - Pain relief and management of other unpleasant symptoms are the main care practices for the patient with sepsis; } \\
\text { - It is important that nurses recognize the signs and symptoms of sepsis so that they can intervene in quickly and appropriately } \\
\text { manners; } \\
\text { - As prevention, it is important to know the mechanisms of infection transmission and the importance of hand washing, proper } \\
\text { aseptic technique and use of personal protective equipment. }\end{array}$ \\
\hline
\end{tabular}

The sample of the integrative review $=$ consisted of 9 articles, of which 2 were published in 2013 $3^{(5,20)}, 3$ in $2016^{(14,16,21)}, 1$ in 2017(15) and 3 in $2018^{(17-19)}$. Regarding language, 4 were in Portuguese $\mathrm{e}^{(17-20)}$ and 5 in English ${ }^{(5,14-16,21)}$. As for country, 4 are from Brazil ${ }^{(17-20)}, 1$ from Norway ${ }^{(14)}$ and 4 from the United States of America ${ }^{(5,14,20-21)}$. Of the 9 articles, only 1 was conducted by a team of internal medicine, while the remaining authors were nurses, demonstrating the relevance of the theme to this community. Chart 2 presents the synthesis of the articles included in the review and Chart 3 shows the main results.

\section{DISCUSSION}

Sepsis is still considered a fatal disease all over the world, with high mortality rates. There are barriers to the identification, control and prevention of this problem, since all studies analyzed reinforce the need to create/implement rapid response protocols ${ }^{(23)}$. These protocols guide the nurse's approach to patients with possible signs of sepsis, allowing the implementation of fast and safe actions and preventing deterioration of their clinical condition.

It has been demonstrated that each hour of delay in antibiotic administration is associated with an increase in mortality of $7.6 \%{ }^{(24)}$. Nurses have a key role in this area, since, according to recommendations, they must obtain appropriate blood cultures before initiating antimicrobial therapy ${ }^{(5)}$. For this, a highly trained nursing team and good articulation/communication with the medical team are necessary in order to avoid failures and delays throughout the process.

Scarce and ineffective communication between the multidisciplinary team members contributes to the occurrence of adverse effects, which may harm the patient, prolong the length of stay, increase resource consumption and lead to professional dissatisfaction ${ }^{(25)}$. One of the studies points to the importance of effective communication within the team, demonstrating that lack of communication can compromise the diagnosis and treatment and contribute to the progression of sepsis. After training the nursing teams on the theme, using role-playing, they report feeling more confident, comfortable and experienced to transmit information to the medical team ${ }^{(16)}$. The nurse is still considered essential in the coordination of the communication between the professional team and the patient/family, given that their proximity to the patient allows establishing a relationship of trust and empathy, making these professionals essential for the provision of humane care ${ }^{(16)}$.

Establishing standardized systems by creating protocols is of critical importance. One of the studies analyzed was conducted in two hospitals and found that, after the implementation of a sepsis screening tool adapted for infirmaries, the number of identified sepsis cases increased from 6.7\% to $84.2 \%$ in hospital 1 and from $22.6 \%$ to $45.2 \%$ in hospital 2 . Mortality rates decreased, as did the need for advanced treatment in intensive care units ${ }^{(14)}$.

Another study found that, after the implementation of a sepsis screening tool by nurses in surgical units of two hospitals, sepsis identification improved and time of notification was shorter, allowing a more rapid initiation of appropriate treatment. The results were so positive that the researchers proposed to adapt this project to all medical-surgical units of these hospitals ${ }^{(15)}$. The use of protocols allows early identification through more rigorous assessment and appropriate monitoring, facilitating the nursing approach and preventing disease progression.

It is necessary to train nurses on the problem of sepsis, with a need for a critical and specialized perspective. This was, it is possible to correctly identify, control and event prevent sepsis. Continuous training of nurses is not only a form of personal and professional development, but also serves as support for practice, contributing to the improvement of the care provided ${ }^{(26)}$.

One of the studies in this review found that nurses in an intensive care unit have knowledge about sepsis prevention and control, however, show some deficiencies in defining concepts and naming forms of treatment. Only $11.1 \%$ of the nurses in this study recognized hypothermia as a possible sign of sepsis, and only $11.1 \%$ listed dyspnea, tachypnea, and altered level of consciousness as alarm signs. Lack of knowledge about the clinical picture may delay the diagnosis, leading to a deterioration of the patient's general condition ${ }^{(20)}$.

Studies ${ }^{(24,27)}$ show that the patient with sepsis has altered physiological parameters 8 hours before, and their survival depends on the ability of the nurse to recognize these changes. It is essential to train the nursing teams, since the nurse is the professional who has the most contact with the patient Therefore, nurses must be able to promptly identify these alterations and act in rapid, safe and well-founded manner. 
One of the studies presented found that, after receiving training on pathophysiology, risk factors, assessment and new guidelines of Surviving Sepsis Campaign, nurses reported they felt significantly more experienced on the subject and more comfortable to recognize and initiate treatment for sepsis. After their training there was also a decrease in the number of patients who received incorrect screening (from $40.6 \%$ to $8.9 \%)^{(16)}$.

Therefore, sepsis requires a holistic approach from the nurse, who must also know that standardized evaluations may not be the answer to this problem. However, as it is an increasing health problem, it is necessary to have trained teams, expert and able to act in effective manners. A constant search for knowledge and investment in training are essential to prevent, identify and fight against sepsis ${ }^{(17-18,28)}$.

Prevention of healthcare associated infections is a central area in nursing care, in which nurses have a leading role. Not all of these infections can be avoided, but they can be prevented when health professionals adhere to good practices in the context of infection prevention and control ${ }^{(29)}$. In this review, four articles highlighted the importance of the nurse in this context. Professionals must have detailed knowledge of the mechanisms of infection transmission: identify possible sources of contamination, use aseptic technique in invasive procedures, perform antisepsis of surfaces and equipment, prepare medication in appropriate environment, wear personal protective equipment when necessary and wash hands before and after any procedure ${ }^{(18-19,22)}$.

The implementation of programs for infection prevention and control at hospitals and the creation of campaigns to raise awareness among health professionals and general population are measures that contribute to increase knowledge about safety and sepsis prevention.

\section{Study limitations}

The limitations are related to the fact that only EBSCO databases and one search engine (Google Scholar) were consulted and only articles in Portuguese or English were selected.

\section{Contributions to the area of nursing, health or public policy}

The nurse has a central role in the care for the critical patient with sepsis, with crucial importance in early identification and intervention.
Healthcare institutions should invest in the implementation, monitoring and evaluation of training programs, ensuring quality care and, consequently, reducing morbidity and mortality. Thus, healthcare gains are expected to occur, reducing the economic and social impact of the disease.

The implementation of programs for infection prevention and control at hospitals and the creation of campaigns to raise awareness among health professionals and general population are measures that contribute to increase knowledge about safety and sepsis prevention.

Considering the results and the importance of this theme, it is necessary to enhance research on the autonomous interventions of nurses for critical patients with sepsis, since they are already present in the literature. The scarcity of literature also demonstrates the importance of continuing to carry out studies in this area, specifically primary studies.

\section{FINAL CONSIDERATIONS}

With an increasing prevalence in hospitals, sepsis is currently a real public health problem. In this review, we reinforced the important role of nurses in the identification, prevention and control of sepsis in critical patients.

Benefits of the implementation of screening protocols/tools were identified, as these tools can help nurses to recognize the problem, ensuring safe, correct and targeted interventions. Early actions from nurses can improve the quality of life of patients with sepsis, minimizing the incidence of multiple organ dysfunction.

The integrative review of literature confirms that training has a decisive influence on practice and can lead to faster, assertive and confident interventions in all stages of sepsis, preventing disease progress. Up-to-date scientific and practical knowledge ensures quality care and, consequently, reduces morbidity, mortality, and the economic and social impact of the disease.

Detailed knowledge of the mechanisms of infection transmission is essential for sepsis prevention, as well as using personal protective equipment during all procedures. It is still necessary to continue investigating this topic, as it is an area in constant update. Therefore, this topic should still be discussed and debated in the scientific community.

\section{REFERENCES}

1. Ordem dos enfermeiros (PT). Regulamento das competências do enfermeiro especialista em enfermagem em pessoa em situação crítica. [Internet]. Lisboa: Ordem dos enfermeiros. 2010[cited 2018 Sep 22]. 4p. Available from: http://www.ordemenfermeiros.pt/legislacao/ Documents/LegislacaoOE/RegulamentoCompetenciasPessoaSituacaoCritica_aprovadoAG20Nov2010.pdf

2. Bone RC, Balk RA, Cerra FB, Dellinger RP, Fein AM, Knaus WA, et al. Definitions for sepsis and organ failure and guidelines for the use of innovative therapies in sepsis. The ACCP/SCCM Consensus Conference Committee. American College of Chest Physicians/Society of Critical Care Medicine. 1992. Chest. 2009;136(5 Suppl). doi: 10.1378/chest.101.6.1644

3. Direção Geral da Saúde (PT). Criação e implementação da Via Verde de Sépsis [Internet]. Lisboa. 2010 [cited 2018 Sep 22] 20p. Available from: https://www.dgs.pt/?ci=554\&ur=1\&newsletter=224

4. Kleinpell R. Promoting early identification of sepsis in hospitalized patients with nurse-led protocols. Crit Care [Internet]. 2017 [cited 2018 Sep 25];21(1):10. Available from: https://doi.org/10.1186/s13054-016-1590-0

5. Kleinpell R, Aiken L, Schorr C. Implications of the new international Sepsis Guidelines for nursing care. AJCC. [Internet] 2013 [cited 2018 Sep 25];22(3):212-22. Available from: http://ajcc.aacnjournals.org/content/22/3/212.full 
6. Dellinger RP, Levy MM, Rhodes A. Annane D, Gerlach H, Opal S, Moreno R. Surving Sepsis Campaign: international guidelines for management of severe sepsis and septic shock. Intensive Care Med [Internet] 2012 [cited 2018 Sep 25];39:165-228 Available from: http:// link.springer.com/article/10.1007/s00134-012-2769-8

7. Fortin MF. O processo de investigação: da concepção à realização. 3a Ed. Loures: Lusociência; 2003.

8. Whittemore R, Knafl K. The integrative review: uptade methodology. J Adv Nurs. [Internet]. 2005 [cited 2018 Sep 22]52(5):546-53. Available from: http://citeseerx.ist.psu.edu/viewdoc/download?doi=10.1.1.465.9393\&rep=rep1\&type=pdf

9. Ramalho A. Manual: Redação de estudos e projetos de revisão sistemática com e sem metanálise. Formasau; 2005

10. Roman AR, Friedlander MR. Revisão integrativa de pesquisa aplicada à enfermagem. Cogitare Enferm. 1998;3(2):109-12. doi: 10.5380/ ce.v3i2.44358

11. Neto JMR, Marques DKA, Ferandes MGM, Nóbrega MML. Meleis Nursing Theories Evaluation: integrative review. Rev Bras Enferm. 2016;69(1)162-8. Available from: doi.org/10.1590/0034-7167.2016690123i

12. The Joanna Briggs Institute. Supporting Document for the Joanna Briggs Institute Levels of Evidence and Grades of Recommendation. [Internet] 2014. [cited 2018 Sep 20]. 18p. Available from: http://joannabriggs.org/assets/docs/approach/Levels-of-EvidenceSupportingDocuments-v2.pdf

13. The Joanna Briggs Institute. New JBI Levels of Evidence [Internet] 2013 [cited 2018 Sep 20] 6p. Available from: http://joannabriggs.org/ assets/docs/approach/JBI-Levels-of-evidence_2014.pdf

14. Torsvik M, Gustad LT, Mehl A, Bangstad IL, Vinje LJ, Damas JK, Solligard E. Early identification of sepsis in hospital inpatients by ward nurses increaes 30-day survival. Crit Care [Internet]. 2016 [cited 2018 Sep 29]20(1):1-10. Available from: https://ccforum.biomedcentral.com/ articles/10.1186/s13054-016-1423-1

15. O'Shaughnessy J, Grzelak M, Dontsova A, Braun-Alfano I. Early Sepsis Identification. Medsurg Nurs [Internet]. 2017 [cited 2018 Sep 30]26(4):248-52. Available from: https://search.proquest.com/docview/1929674571?accountid=41313

16. Drahnak DM, Hravnak M, Ren D, Haines AJ, Tuite P. Scripting nurse communication to improve sepsis care. Med Surg Nurs[Internet] 2016 [cited 2018 Oct 1];25(4):239.Available from: https://www.researchgate.net/ publication/321712411_Scripting_nurse_communication_to_improve_sepsis_care

17. Miranda LFB, Capistrano RL, Souza SA. Atuação do enfermeiro emergencista no controle de sepse. Rev Electrôn Atualiza Saúde [Internet] 2018[cited 2018 Oct 2]7(7):76-83. Available from:http://atualizarevista.com.br/wp-content/uploads/2018/02/atua\%C3\%A7\%C3\%A3o-doenfermeiro-emergencista-no-controle-de-sepse-v7-n7.pdf

18. Silva APRM, Souza HV. Sepse: Importância da identificação precoce pela enfermagem. Revista Pró-Univer SUS [Internet]. 2018 [cited 2018 Oct 2]09(1):97-100: Available from: http://editora.universidadedevassouras.edu.br/index.php/RPU/article/viewFile/1266/948

19. Sousa MST, Ferreira FS, Silva NRM, Soares NS, Silva LM, Morais AP. Assistência de enfermagem a pacientes com sepse na unidade de terapia intensiva: uma revisão de literatura. REAS/JECH [Internet]. 2018 [cited 2018 Oct 2]13:1458: Available from: http://dx.doi.org/10.25248/REAS289_2018

20. Almeida APSR, Belchior PK, Lima MG, Souza LP. Conhecimento do profissional de enfermeiro a respeito da sepse. Braz J Surg Clin Res[Internet]. 2013 [ cited 2018 Sep 25]4(4):5-10 Available from: https://www.mastereditora.com.br/periodico/20131102_1144092.pdf

21. Schorr C. Nurses can help improve outcomes in severe sepsis. Am Nurse Today [Internet]. 2016 [ cited 2018 Sep 29] 11(3). Available from: https://www.myamericannurse.com/nurses-can-help-improve-outcomes-severe-sepsis/

22. The Joanna Briggs Institute. Critical Appraisal Tools [Internet] 2017 [cite 2018 Oct 2]. Available from: http://joannabriggs.org/research/ critical-appraisal-tools.html

23. Scheidt SN, Bordin D, Aguiar LN, Tracz EC, Arcaro G, Farago PV, el al. Implantação do Protocolo de Manejo de Sepse no Pronto Atendimento do Hospital Universitário Regional dos Campos Gerais. Rev Epidemiol Controle Infec [Internet]. 2018 [cited 2018 Oct 2];8(1):54-64. Available from: https:// online.unisc.br/seer/index.php/epidemiologia/article/view/9974/7784

24. Kumar A, Roberts D, Wood KE, Light B, Parrillo JE, Sharma S, et al. Duration of hypotension before initiation of effective antimicrobial therapy is the critical determinant of survival in human septic shock. Crit Care Med [Internet]. 2006 [cited 2018 Oct 3];34(6):1589-96 Available from: https://journals.Iww.com/ccmjournal/Abstract/2006/06000/Duration_of_hypotension_before_initiation_of.1.aspx

25. Leonard M, Graham S, Bonacum D. The human factor: The critical importance of effective teamwork and communication in providing safe care. Qual Saf Health Care [Internet]. 2004 [cited 2018 Oct 5]13:85-90 Available from: https://www.ncbi.nlm.nih.gov/pubmed/15465961

26. Salgueira AP, Frada T, Aguiar P, Costa MJ. Aprendizagem ao longo da vida do médico - tradução e adaptação da Escala de Jefferson. Act Med Port [Internet] 2009 [cited 2018 Oct 28]22(3):247-56 Available from: https://www.actamedicaportuguesa.com/revista/index.php/amp/ article/viewFile/1699/1279

27. Westphal GA, Pereira AB, Fachin SM, Sperotto G, Gonçalves M, Albino L, et al. Um sistema eletrônico de alerta ajuda a reduzir o tempo para diagnóstico de sepse. Rev Bras Ter Intensiva [Internet] 2018 [cited 2018 Oct 30]30(4):414-422. Available from: https://doi. org/10.5935/0103-507x.20180059

28. Ribeiro AR, Gonçalves MS, Pereirs GCS. Ações do Enfermeiro na Identificação precoce da Sepse. Enferm Rev [Internet] 2018 [cited 2018 Nov 1]21(2)27-49 Available from: http://periodicos.pucminas.br/index.php/enfermagemrevista/article/view/18821/13932

29. Curtis LT. Prevention of hospital-acquired infections: review of nonpharmacological interventions. J Hosp Infect [Internet] 2008. [cited 2018 Nov 3]69:204-19 Available from: https://dx.doi.org/10.1016/j.jhin.2008.03.018 